愛媛大学第 1 外科（主任：小林展章教授）

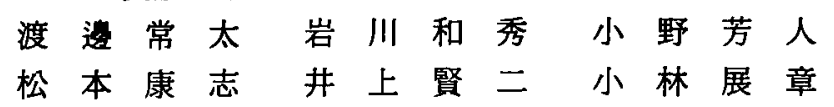

一般に Wernicke 脳症は慢性アルコール中毒症の患者に多発するといわれている. 今 回われわれは飲酒歴がないにもかかわらず，胃全摘術後にWernicke 脳症を発症した 1 例を経験したので報告する，症例は46歳，女性. 心䆟部不快感を主訴に来院，諸検査に て胃癌と診断され胃全摘術を施行した。術後食事摄取進まず,術後約100日目より眼球運 動障害, 小脳性失調, 意識障害を認めた。頭部 MRI の T2強調像にて第 3 脳室から中脳 水道周囲にかけて左右対称的な高信号域を認め, Wernicke 脳症と診断した。治療として ビタミン $B_{1}$ 持続点滴投与を行い約40日でほほ軽快した. 胃全摘術後は栄養学的観点か ら，ビタミン $\mathrm{B}_{1}$ 欠乏を起こしやすく，本症にも留意する必要がある．また，Wernicke脳 症の診断には頭部 MRI が有用であった.

索引用囍：Wernicke 脳症, 胃全摘, MRI

\section{緒 言}

Wernicke 脳症は臨床的には眼球運動障害, 小脳性 失調, 意識障害を 3 主徵とする疾患であり, 日常診療 上実際に遭遇することは決して多くない，本症はビタ ミン $\mathrm{B}_{1}$ 欠乏を原因とし，慢性アルコール中毒患者に多 発し，欧米での報告は多いが本邦での報告例は少ない。 今回われわれは胃全摘術後に発症したWernicke 膇症 を経験し，その診断に Magnetic Resonance Imaging (以下 MRI)が有用であったので, 文献的考察を加え報 告する.

\section{症例}

患者：46歳，女性.

主訴: 心蓇部不快感。

家族歴：特記すへきことなし.

既往歴：昭和55年, 甲状腺腫湯核出術（当院耳鼻咽 唉科).

現病歴：平成 2 年より心裔部不快感, 食欲不振あり, 近医にて上部消化管造影施行したが胃炎と診断され内 服治療を受けていた。しかし症状改善なく 2 年間で約 $10 \mathrm{~kg}$ の体重隇少を認めたため, 平成 6 年 7 月当院内科 受診し胃内視鏡検查にて胃癌と診断され，手術目的に て 8 月24日当科転科となる.

1996年 1 月 18 日受付 1996 年 6 月 4 日採用
入院時現症：身長 $157 \mathrm{~cm}$, 体重 $47 \mathrm{~kg}$, 栄責状態良好, 結膜に賓血, 黄染なし. 腹部は平坦で, 心裔部に径 $10 \times$ $5 \mathrm{~cm}$ の弾性硬, 可動性やや不良な腫瘤を触知したが圧 痛は認めなかった。体表のリンパ節は触知せず, 神経 学的に異常所見を認めなかった.

入院時検査所見：血液検査にて軽度貧血を認め, 血 液生化学検查にて総蛋白, 脂質の低下を認めた. 血清 鉄は術前の鉄郕投与のため高值を示し, 腫場マーカー は正常範囲内であった (Table 1).

Table 1 Laboratory data on admission

\begin{tabular}{|c|c|c|c|}
\hline \multicolumn{2}{|c|}{ Hematological data } & $\mathrm{LDH}$ & $241 \mathrm{IU} / l$ \\
\hline WBC & $4.0 \times 10^{3} / \mu 1$ & Chol & $191 \mathrm{mg} / \mathrm{dl}$ \\
\hline $\mathrm{RBC}$ & $4.61 \times 10^{5} / \mu 1$ & P. Lipid & $184 \mathrm{mg} / \mathrm{dl}$ \\
\hline$\underline{\mathrm{Hb}}$ & $10.5 \mathrm{~g} / \mathrm{dl}$ & T.G. & $59 \mathrm{mg} / \mathrm{dl}$ \\
\hline $\mathrm{Ht}$ & $31.5 \%$ & BUN & $10 \mathrm{mg} / \mathrm{dl}$ \\
\hline Plt & $32.0 \times 10^{4} / \mu 1$ & Cre & $0.6 \mathrm{mg} / \mathrm{dl}$ \\
\hline \multicolumn{2}{|c|}{ Biochemical data } & $\mathrm{Fe}$ & $166 \mu \mathrm{g} / \mathrm{dl}$ \\
\hline T.P. & $5.5 \mathrm{~g} / \mathrm{dl}$ & \multicolumn{2}{|c|}{ Tumor marker } \\
\hline $\mathrm{A} / \mathrm{G}$ & 1.6 & CEA & $0.2 \mathrm{ng} / \mathrm{ml}$ \\
\hline T. Bil & $0.4 \mathrm{mg} / \mathrm{dl}$ & CA19-9 & $15.6 \mathrm{U} / \mathrm{ml}$ \\
\hline Ch. E & $182 \mathrm{IU} / l$ & TPA & $40.6 \mathrm{U} / l$ \\
\hline GOT & $12 \mathrm{IU} / l$ & CA72-4 & $3.1 \mathrm{U} / \mathrm{ml}$ \\
\hline GPT & $10 \mathrm{IU} / l$ & & \\
\hline ALP & $82 \mathrm{IU} / l$ & & \\
\hline$\gamma \cdot \mathrm{GTP}$ & $15 \mathrm{IU} / \mathrm{ml}$ & & \\
\hline LAP & $24 \mathrm{IU} / l$ & & \\
\hline
\end{tabular}




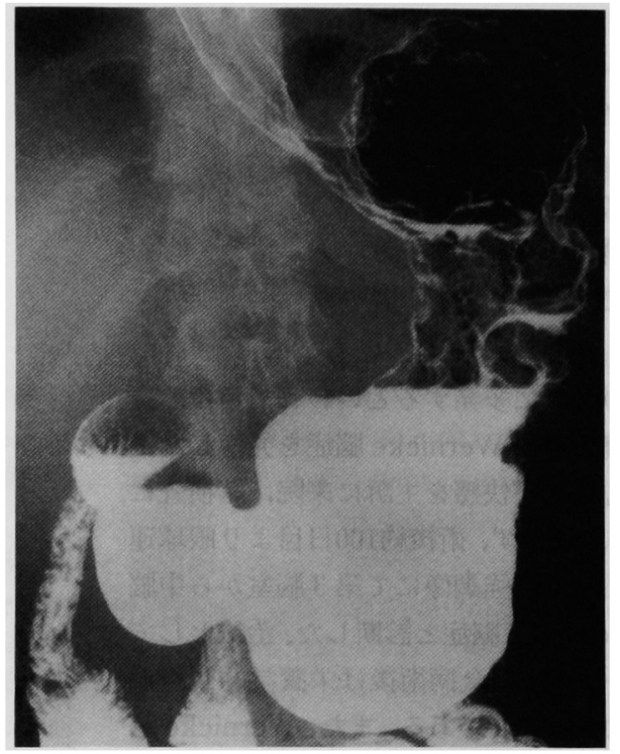

Fig. 1 Upper gastrointestinal series shows irregular surface and circular stenosis on cardia and upper body of stomach.

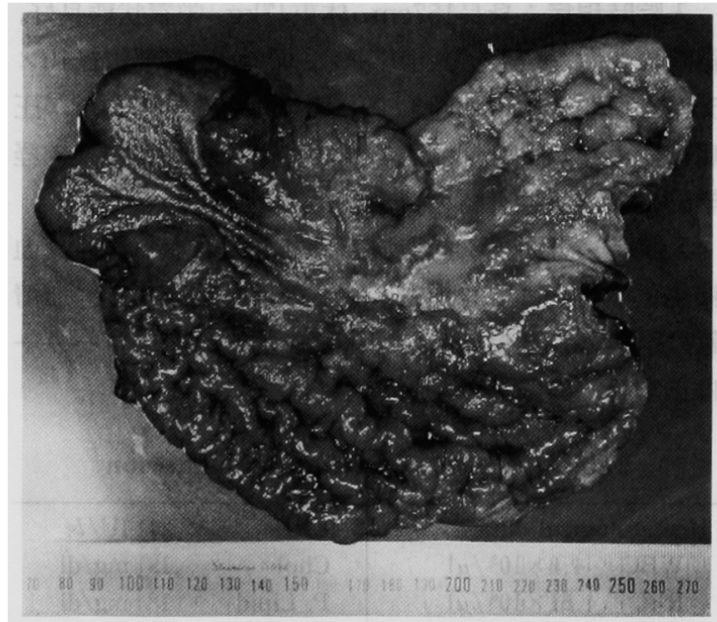

Fig. 2 Macroscopic finding of the resected specimen shows type IV advanced gastric cancer.

上部消化管造影：腹部食道から胃体中部にかけてほ ほ全周性の壁の伸展不良および硬化像を認めた（Fig. 1).

胃内視鏡検查：胃内腔が狭く大弯を中心に壁の伸展 不良を認め，病変の境界は不明暸であった。生検にて Group V，腺癌と診断された。

以上より胃癌（IV型）と診断し，平成 6 年 8 月 30 日 手術を施行した。

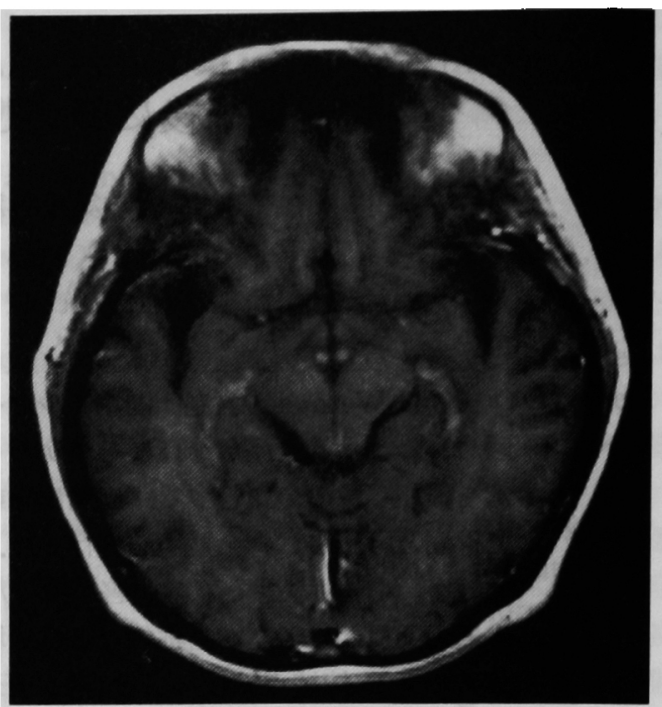

Fig. 3 T1-weighed MRI which is enhanced by Gd DTPA shows high intensity areas in the mamil. lary bodies.

手術所見：開腹時所見にて胃噴門部から胃体部にか けて獎膜面は白色肥厚し, 明らかな病変の漿膜露出を 認め，また病変は脾門部へ浸潤していた．更に横行結 腸の大網付着部に白色の硬結を認め, 迅速病理検查に て腺癌と䛦断された，以上よりリンパ節郭清を伴う胃 全摘, 膵尾部脾合併切除, 横行結腸部分切除, 腹膜播 種に対し腹腔内カテーテル留置術を行いRoux-en-Y 法にて再建した。胃癌取り扱い規約上は CME, circ, $\mathrm{t}_{3}, \mathrm{n}_{2}$ (No. 3, 4sa, 4sb, 4d, 7,8a, 10k陽性), $P_{1}$, $\mathrm{H}_{0}, \mathrm{M}_{0}$, Stage IVa, $\mathrm{D}_{2}$ 郭清, 根治度 C (Fig. 2) で あった。

術後経過：経過良好にて術後 7 日目より中心静脈栄 養内のビタミン剤を中止し，術後 8 日目より食事を開 始した。しかし胆書炎を併発し術後11日目より10日間 絶食とした。術後 1 力月目より化学療法 (MTX 50mg, 5 -FU 750mg) を 5 クール施行, 又術後 3 カ月目に腹腔 内カテーテルより CDDP 50mg, 5-FU 750mg を注入 した。この後化学療法の副作用および患者の強い偏食 傾向のため食事㨟取は平均 3 割程度しか進まなかっ た。 その間中心静脈栄養にて約 $500 \mathrm{kcal} /$ 日持続投与し た.

術後104日目にめまいおよび頭重感を訴え，術後108 日目に複視および見当識障害が出現した。術後112日目 には失調性歩行を認め, 食事摂取の際に介助が必要と なり，同時に傾眠傾向（Japan Coma Scale II-20，以 


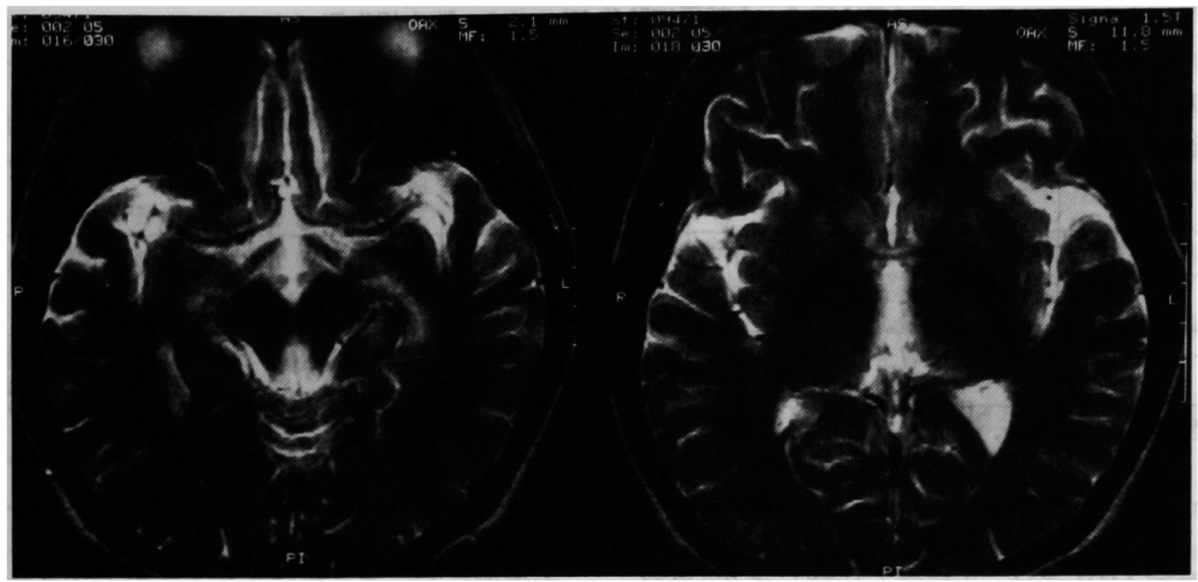

Fig. 4 T2-weighed MRI shows symmetrical high intensity areas in the 3rd ventricle (left) and periaquedactal regions (right).

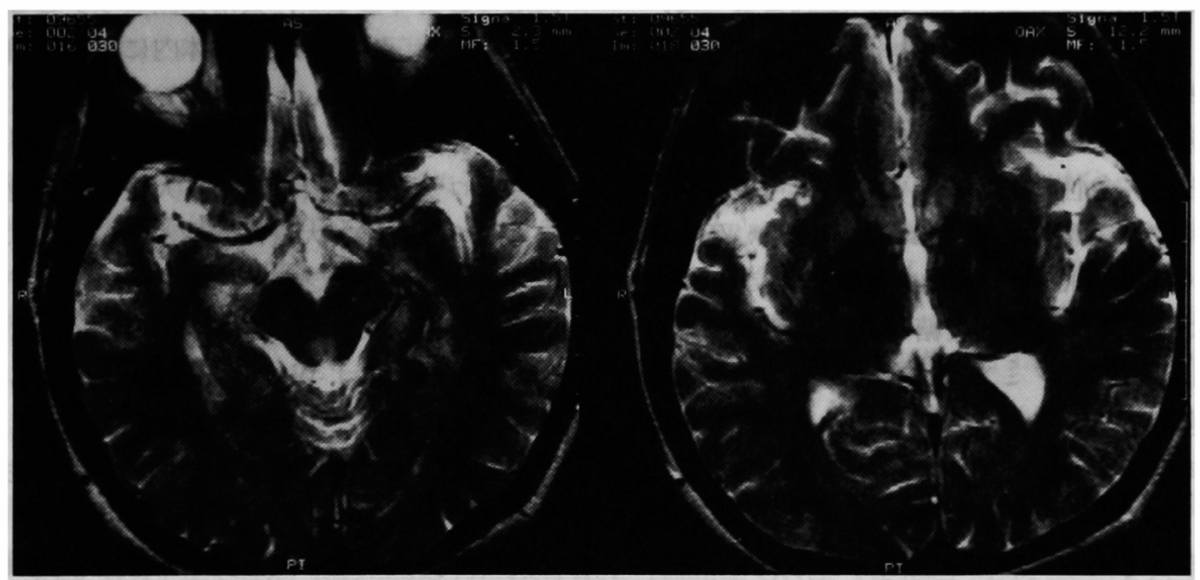

Fig. 5 Symmetrical high intensity areas in the 3 rd ventricle (left) and periaqueductal regions (right) disapered on T2-weighed MRI.

下 JCS)も出現した。術後118日目にはほとんどベット 上臥位の状態となった。この際眼症状として右外転神 経麻㿎および右水平性眼振を認めた。四肢の運動性麻 疸は認めず，上肢深部腱反射は正常であった。アキレ 又腱反射および膝蓋腱反射は両側低下し, 病的反射は 認めなかった. room air 下血液ガス分析は $\mathrm{pH} 7.56$, Base excess +5.5と代謝性アルカローシスを示した. 脳波ではびまん性の徐波を認めた. Single Photon Emission Computed Tomography では右前頭葉領域 の血流の低下を認め, 又筋電図では特に所見を認めな かった. ビタミン $\mathrm{B}_{1}$ 値は $5.6 \mu \mathrm{g} / \mathrm{dl}$ (正常值4.4 11.2) と正常下限であった。

頭部 CT：特記すぺき所見なし.
頭部 MRI：造影 Gd DTPA による T1強調像にて, 乳頭体が強く増強された(Fig. 3). T2強調像にて, 第 3 脳室から中脳水道周囲にかけて脳室周囲が対称的に 高信号に描出された（Fig. 4).

以上の所見より Wernicke 脳症と診断し, 術後118日 目よりビタミン $\mathrm{B}_{1}$ 約 $50 \mathrm{mg}$ と総合ビタミン剂の点滴 静注を開始した。翌日（術後119日目）には複視および 右外転神経麻痺は消失し, 意識障害も JCS I-3まで改善 した.ビタミン剤投与開始後16日目 (術後134日目)に 自力で食事摄取可能となった. 又失調性歩行も徐々に 改善し, ビタミン斉投与開始後 5 日目 (術後113日目) に介助歩行開始し，22日目 (術後140日目) 独歩可能と なった.ビタミン剤投与開始後37日目 (術後154日目) 
Table 2 本邦用切除後 Wernicke 脳症報告例

\begin{tabular}{|c|c|c|c|c|c|c|c|c|c|}
\hline No. & 報告者 & 年度 & 年些命, 性別 & $\begin{array}{l}\text { 術式及び } \\
\text { 再建法 }\end{array}$ & $\begin{array}{l}\text { 手術より } \\
\text { 発症まて } \\
\text { の期間 }\end{array}$ & 酰床症状 & 影断法 & 治 & 転㷌 \\
\hline 1 & 服部ら & 1987 & $42 y, \quad F$ & 胃全摘 & 2 年 & $\begin{array}{l}\text { 食欲不振, 両下肢脱 } \\
\text { 力感, 複視等 }\end{array}$ & 病理解剖 & 施行せず & 死亡 \\
\hline 2 & 沖野ら & 1993 & $63 y, \quad F$ & $\begin{array}{l}\text { 胃切除, } \\
\text { 空空腸吻 } \\
\text { 合 }\end{array}$ & 30年 & $\begin{array}{l}\text { 下肢の浮䏸 ·しU゚れ } \\
\text { 感, 複視, 作話等 }\end{array}$ & $\begin{array}{l}\text { 頍部 MRI, } \\
\text { SPECT }\end{array}$ & ビタミン $B_{1}$ 大量投与 & 軽快 \\
\hline 3 & 谷ら & 1995 & $46 y, \quad F$ & 贯全摘 & $30 \mathrm{~B}$ & $\begin{array}{l}\text { 低体温, 意識障害, } \\
\text { 眼振等 }\end{array}$ & $\begin{array}{l}\text { 臨床経過, } \\
\text { 身体所見 }\end{array}$ & $\begin{array}{l}\text { ビタミン } \mathrm{B}_{1} \text { 大量投与, } \\
\text { ステロイド・バル潦法 }\end{array}$ & 治䆻 \\
\hline 4 & 渡息ら & 1996 & $46 y, F$ & $\begin{array}{l}\text { 胃全摘, } \\
\text { Roux. } \\
\text { en-Y 法 }\end{array}$ & 104日 & 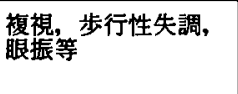 & 頭部 MRI & ビタミン B,大量投与 & 軽快 \\
\hline
\end{tabular}

に撮影した頭部 MRIでは，治療前と比較して T2強調 像における明らかな高信号域の縮小を認めた（Fig. 5).ビタミン刘投与開始後 40 日目（術後158日目）に， 軽度意識障害を残したまま（JCS I-1）退院となった。

\section{考 察}

Wernicke 脳症は1881年 Wernickeにより初めて発 表され，臨床的に眼球運動障害，小脳性失調，意識障 害を 3 主徵とし, 急性期の治療により回復可能な病態 であるが，時には重篤となり死にいたり，幸い死を逃 れた場合でもKorsakoff 症候群を後に残すことが多 い”．本症は解糖系および五炭精リン酸系の補醭素と して働く thiamine (ビタミン $\mathrm{B}_{1}$ ) 久乏がその原因とさ れており，慢性アルコール中毒患者に多発することは よく知られている。しかしアルコール以外にもビタミ ン $\mathrm{B}_{1}$ 低下をきたしうる疾患はすべてWernicke脳症 を起こしうると考えられ，その原因としてアルコール とは無関係の栄盖障害での発生 ${ }^{2)}$, 重症奷娠悪阻 ${ }^{2)}$, ビ タミンを含まない長期の中心静脈栄養 ${ }^{3}$, 胃切除 後(2)-4), 人工透析患者 ${ }^{122}$, 重症感染症 ${ }^{1)}$, 悪性疾患 ${ }^{2) な ~}$ どが報告されている. 又ビタミン $\mathrm{B}_{1}$ の吸収は大部分十 二指腸で行われるため5)，胃全摘術後は食物の流動状 態の変化によりビタミン $\mathrm{B}_{1}$ はもとより，腸管からの 種々の栄養素の消化吸収が障害され全身の栄養素の低 下をきたすことも多い。本症例に抢ける発症の原因は， 元来偏食傾向が強かったこと, Roux-en-Y 再建法によ り食物が十二指腸を通過しなくなったこと，更に術後 化学療法を行い経口摂取が不良となり，ビタミン剤を 含まない中心静脈栄養が長期にわたったこと等が挙げ られる。

Wernicke 脳症の診断については 3 主徵に注意する ことが必要であるが，常にすべてが現われるとは限ら ず, 意識障害が最初で唯一の症状となることもある
本症例においては最終的に 3 主街が出そろったが, 眼 球運動障害が先行し，続いて失調と意識障害がほほ平 行して進行した. 検查所見としては血中ビタミン $\mathrm{B}_{1}$ の 測定は必要であるが，異常低值ならずとも本症は起こ りうる゙．ビタミン $\mathrm{B}_{1}$ は生体内において補醉素として 解梼系および TCA サイクル，とりわけピルビン酸か らアセチル CoA への脱炭酸反応に深く関与する. 更 に高カロリー輸液などにより大量の精が投与された場 合はピルビン酸が大量に産生され，ビタミン $\mathrm{B}_{1}$ の需要 増加から相対的欠乏が生じると考えられている。この ため本症例においてはビタミン $\mathrm{B}_{1}$ 值は正常下限だっ たにもかかわらず Wernicke 脳症を発症したと考えら れる。 また血中ピルビン酸は上昇を認め, 血液ガス分 析ては代謝性アシドーシスを示すが特異性に乏しいと されており"，脳波では約半数の例でびまん性の徐波 を認める. 更に近年画像診断が注目され頭部 CTでは 脳室周囲に低吸収領域を認めることが多い177)。頭部 MRI では急性期の特徵として視床背内側核, 第 3 脳 室, 中脳水道近傍に T2強調画像にて左右対称性の高 信号領域を諗めることが多く，血管障害や多発性硬化 症との盘別点として病変の左右対称性が挙げられ る4). 病理学的には視床内側核群, 乳頭体, 脳室周囲の 灰白質の急性期における血管内皮細胞の膨化および点 状出血と, それに続く血管の増生, グリオージスが特 徵である(1)8. また T1強調像において乳頭体が強く增 強され，慢性期の乳頭体の萎樎を示す所見とされてい

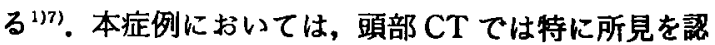
めなかったが，頭部 MRIにおいて造影 Gd DTPAに よる $\mathrm{T} 1$ 強調像にて第 3 脳室から中脳水道周囲にかけ て対称性に高信号に描出されWernicke 脳症に特異的 な所見が得られ診断に有用であった。

治療においては，急性期にはただちに100から250 
$\mathrm{mg} /$ 日のビタミン $\mathrm{B}_{1}$ の静脈内投与を行うべきである とされており名 10), 眼球運動障害はビタミン $B_{1}$ 投与開 始直後に改善され, 失調は 1 週間以内に, 意識障害は $1 \sim 2$ 週間で改善傾向がみられることが多い. 本症例 においてはビタミン $B_{1}$ と総合ビタミン剤の投与開始 翌日には眼球運動障害が改善し, 続いて小脳性失調が 改善し，投与開始後40日にて軽い健忘を残すまで回復 した. 胃切除術後の Wernicke 脳症の報告例はわれわ れが検索し得た範囲内では本邦で 4 例 (Table 2) と稀 ではあるが, 病態から考えると十分考虑に入れる必要 があると思われた. 今後も経口によるビタミン攝取障 害があるため,ビタミン $\mathrm{B}_{1}$ および総合ビタミン剤の定 期的な経静脈投与を継続する必要があると思われる。

$$
\text { 結語 }
$$

胃全摘術後に Wernicke 脳症を発症した 1 症例を経 験したので若干の文献的考察を加え報告した。尚, Wernicke 脳症の診断には頭部 MRI が有用であった。 文 献

1）谷口 浩, 三山吉夫：傾眠・塞動を主症状とし，第 3 脳室・中脳水道周囲に限局性病変を認めた 1 症 例. 九州神精医 $39: 37-43,1993$

2) Ebels EJ : Underlying illness in Wernicke's encephalopathy. Europe Neurol 12:226-228, 1974
3）谷卓, 吉本勝博, 高村博之他：ステロイドーパ ルス療法が著奻を奏した胃全摘術後ウエルニッケ 脳症の 1 例. 外科と代謝 $29: 381-385,1995$

4）沖野慜一, 坂尻顫一, 福島功二他：胃空腸吻合術か 誘因と考えられた Wernicke-Korsakff syndrome の1例. 臨神経 33:530-534, 1993

5）能勢善嗣：チアミン(ピタミン $\left.\mathrm{B}_{1}\right)$ ビタミン学 II. 日本ビタミン学会編, 東京化学同人, 東京, 1980 , p3

6）合田周一郎, 後藤幾生: Wernicke脳症. 内科 $57: 432-434,1986$

7) Ohkoshi N, Ishii A, Shoji S: Wernicke's encephalopathy induced by hyperemesis gravidarum, associated with bilataral caudate lesions on computed tomography and magnetic resonance imaging. Eur Neurol 34 : 177-180, 1994

8) Vege A, Sund $S$, Lindboe CFR: Wernicke's encephalopathy in an autopsy material obtained over a one-year period. APMIS 99 : 755-758, 1991

9) Heye N, Terstegge K, Sirtl C, et al: Wernicke's encephalophathy-causes to consider. Internsive Care Med 20: 282-286, 1994

10) Lindberg MC, Oyler RA: Wernicke's encephalopathy. AFP 41 : 1205-1209, 1990

\title{
A CASE OF WERNICKE'S ENCEPHALOPATHY AFTER TOTAL GASTRECTOMY
}

\author{
Jota WATANABE, Kazuhide IWAKAWA, Yoshito ONO, Yasushi MATSUMOTO, \\ Kenji INOUE and Nobuaki KOBAYASHI \\ First Department of Surgery, Ehime University School of Medicine
}

\begin{abstract}
Wernicke's encephalopathy is generally caused by chronic alcoholism. We report a case of Wernicke' s encephalopathy after total gastrectomy despite of no history of alcoholism. A 46-year-old woman was admitted to the hospital because of an epigastralgia. Total gastrectomy was performed with a diagnosis of gastric cancer. After the operation she had appetite loss and developed ocular abnormalities, ataxia and disturbance of consiousness. Brain MRI showed symmetrical high intensity areas in the periventricucular region on T2-weighed images. It was typically characterized by Wernicke's encephalopathy. The patient was immediately treated with sustained vitamin B1 IV infusion therapy and restored to health by 40-day treatment. A history of gastrectomy is a risk factor for vitamin Bl deficiency. Wernicke' $s$ encephalopathy should be considered in patients afte total gastrectomy in the nutritional point of view. Bisides brain MRI was useful for the diangosis of Wernicke's encephalopathy.
\end{abstract}

